NBER WORKING PAPER SERIES

\title{
THE PRICE OF NAILS SINCE 1695: \\ A WINDOW INTO ECONOMIC CHANGE
}

\author{
Daniel E. Sichel \\ Working Paper 29617 \\ http://www.nber.org/papers/w29617 \\ NATIONAL BUREAU OF ECONOMIC RESEARCH \\ 1050 Massachusetts Avenue \\ Cambridge, MA 02138 \\ December 2021
}

I would like to thank Ernst Berndt, Daniel Fetter, Robert Gordon, Eric Hilt, Eric Hurst, Nina Pavcnik, Robert Margo, Sam Nelson, Stephen Oliner, Timothy Taylor, Heidi Williams, and participants at the summer 2011 CRIW/NBER Workshop, the summer 2021 Development of the American Economy NBER Summer Institute, a Wellesley College seminar, and other seminars for helpful suggestions and ideas. For assistance on data sources, I thank Gerben Bakker, Joe Davis, Claudia Goldin, Doug Irwin, and Ben Mandel. Peter Chen, Katharine Liang, and Sophie Sun provided excellent research assistance. I also thank Lorna Condon (Senior Curator) for providing access to Historic New England's collection of ephemera and Roelif Loveland (President of Maze Nails) for insights about current manufacturing of nails. Gary Anderson, a fifth-generation nailer at Tremont Nails, kindly took me on a tour of Tremont Nail Company's Mansfield, Massachusetts manufacturing facility. Robert Carver, Brent Neiman, and David Rubin provided assistance in connecting with current nail manufacturers. In addition, a number of librarians were extremely helpful, including Yin Zhu at the Federal Reserve Board and Maureen Booth at the Department of the Interior; Peter Burtch and Deb Fenwick at Northwestern University provided valuable assistance in accessing their library's collection of Sears catalogues.

The author has disclosed additional relationships of potential relevance for this research. Further information is available online at http://www.nber.org/papers/w29617.ack

NBER working papers are circulated for discussion and comment purposes. They have not been peer-reviewed or been subject to the review by the NBER Board of Directors that accompanies official NBER publications.

(C) 2021 by Daniel E. Sichel. All rights reserved. Short sections of text, not to exceed two paragraphs, may be quoted without explicit permission provided that full credit, including ( $)$ notice, is given to the source. 
The Price of Nails since 1695: A Window into Economic Change

Daniel E. Sichel

NBER Working Paper No. 29617

December 2021

JEL No. E01,E30,N11,N12,N61,N62,O14,O33

\begin{abstract}
$\underline{\text { ABSTRACT }}$
This paper focuses on the price of nails since 1695 and the proximate source of changes in those prices. Why nails? They are a basic manufactured product whose form and quality have changed relatively little over the last three centuries, yet the process for producing them has changed dramatically. Accordingly, nails provide a useful prism through which to examine a wide range of economic and technological developments that touch on multiple areas of both micro- and macroeconomics. Several conclusions emerge. First, from the late 1700s to the mid 20th century real nail prices fell by a factor of about 10 relative to overall consumer prices. These declines had important effects on downstream industries, most notably construction. Second, while declining materials prices contribute to reductions in nail prices, the largest proximate source of the decline during this period was multifactor productivity growth in nail manufacturing, highlighting the role of the specialization of labor and re-organization of production processes. Third, the share of nails in GDP dropped back from 0.4 percent of GDP in 1810 - comparable to today's share of household purchases of personal computers - to a de minimis share more recently; accordingly, nails played a bigger role in American life in that earlier period. Finally, real nail prices have increased since the mid 20th century, reflecting in part an upturn in materials prices and a shift toward specialty nails in the wake of import competition, though the introduction of nail guns partly offset these increases for the price of installed nails.
\end{abstract}

\author{
Daniel E. Sichel \\ Department of Economics \\ Wellesley College \\ 106 Central Street \\ Wellesley, MA 02481 \\ and NBER \\ dsichel@wellesley.edu
}

A data appendix is available at http://www.nber.org/data-appendix/w29617 


\section{Introduction}

Nails are a basic manufactured product whose form and quality have changed relatively little since the late $1600 \mathrm{~s}$, and nails produced then would be quite recognizable today (as would nails produced in ancient Rome). Yet, the manufacturing process for nails has changed dramatically, with a shift from artisanal to factory production, a change in power source from hand to water to steam to electricity, and a shift in materials from iron to steel.

Coincident with those changes, the price of nails fell significantly. In this paper, I construct a price index for nails, relative to an index of overall consumer prices, based on data going back to 1695 . The real price of nails fell by a factor of about 10 from the late-1700s to the middle of the $20^{\text {th }}$ century, averaging a decline of about $1-1 / 2$ percent a year. These declines are paltry compared with those for more dramatic examples: for example, Nordhaus (2007) calculated that the real cost of computing dropped by a factor of at least 2 trillion times from 1850 to the early 2000s, while Nordhaus (1997) showed that the real cost of lighting fell by a factor of about 3400 from 1800 to 1992 . However, these vivid examples, while providing important insights, do not particularly shed light on the developments and changes that affect more pedestrian products. We need to look elsewhere for that, and one product that hits the nail on the head is, wait for it, nails. Indeed, these declines in the price of nails provide a useful entry point for deepening our understanding of changes in manufacturing processes, key sources of those changes, and the evolving role of nails in the US economy. Moreover, nails are ideal for this analysis because there has been relatively little change in the product itself (unlike the production of computing power or lighting), thereby greatly simplifying the task of adjusting for changes in quality over time. 
Over the same span of 300-plus years during which these transformations occurred, the place of nails in the economy (and in popular accounts) also underwent a huge shift. In 1810 (the earliest year for which I could assemble necessary data), the use of nails in the US (measured as production plus imports minus exports) was about 0.4 percent of nominal GDP as shown in Figure 1. To put this share into perspective, in 2019 household purchases of personal computers and peripheral equipment amounted to roughly 0.3 percent of GDP and household purchases of air travel amounted to about 0.5 percent. That is, back in the $1700 \mathrm{~s}$ and early $1800 \mathrm{~s}$, nails were about as important in the economy as computers or air travel purchased by consumers are today.

The high value of nails during earlier periods is reflected in the practice of recovering used nails. According to Temin (1964 p. 42), during the 1700s abandoned buildings were sometimes burned down to facilitate the recovery of nails. Even a century later, nails were still highly valued. The well-known novel Little House on the Prairie (Wilder, 1935, p. 124) contains a description of attaching a roof to a log home on the frontier during the 1870 s (after the price of nails had already fallen significantly from the late 1700s), which highlights the value placed on nails: ${ }^{1}$

Now Pa carefully took the nails one by one from his mouth, and with ringing blows of the hammer he drove them into the slab. It was much quicker than drilling holes and whittling pegs and driving them into the holes. But every now and then a nail sprang away from the tough oak when the hammer hit it, and if $\mathrm{Pa}$ was not holding it firmly, it went sailing through the air.

Then Mary and Laura watched it fall and they searched in the grass till they found it. Sometimes it was bent. Then $\mathrm{Pa}$ carefully pounded it straight again. It would never do to lose or waste a nail.

\footnotetext{
${ }^{1}$ Despite the very substantial declines in the relative price of nails documented in this paper, some builders still recover them from construction sites though this now largely is seen as a sign of frugality. For example, the New York Times (1999) reported in the obituary of Fred Trump (Donald's father) that the senior Trump at one of his construction sites "would walk through the studs and across the plywood floors, picking up unused nails to hand back to his carpenters the next day."
} 
Today, 150 years after the period depicted in Little House, the price of nails has fallen far enough (and alternative means of fastening objects together have been developed) so that an individual nail seems cheap and disposable. The importance of nails in the economy, as shown in Figure 1, had dropped to a de minimis share of less than 0.01 percent by 2017 .

This essay investigates the long-term patterns in nail prices and their underlying causes. Some of the facts that emerge include: 1) real prices for domestically produced US-nails fell dramatically up until about $1930 ; 2)$ improvements in multifactor productivity are the main cause of price decline in nails up though the 1930s, although declining prices of materials also play a role; 3 ) reported real nail prices have risen since the 1930s owing partly to rising materials prices but also likely to difficulties in tracking prices of basic nails as US nail producers shifted toward specialty nails in the wake of import competition; and 4) including the complementary technology of nail guns, the price of installed nails has risen much less than the price of nails themselves in recent decades. A recurrent theme that runs throughout the discussion is that changes in the production of even a humble item like the nail are often intertwined with larger technological changes in the US economy that touch on multiple areas of both of micro- and macroeconomics.

\section{A Brief History of Nails}

Nails fall into three broad types — hand forged, machine cut, and wire—with each of these types dominant in each of three overlapping periods as described in Adams (2002), Lewis (1998), and Wells (1998). (Additional details on the timeline and additional source citations are in Appendix Table A1.) Hand-forged nails have been made at least since Roman times and continued to be made in relevant quantities through about 1820 . Forged nails are made by a 
blacksmith (or nailsmith), hammering the nail from a rod of iron and hammering a head on the top.

Cut nails are made by a bladed machine that cuts nails from thin strips of iron or steel. The first patents for cut nails in the United States were granted in the 1770s and 1780s, and a flood of patents followed in subsequent years. The manufacturing technology for cut nails improved dramatically during the 1800 s as production shifted to factories, mirroring many of the developments of the broader industrial revolution. The power source shifted from water to steam and later electricity, and more and more of the individual tasks of nailmaking became mechanized. In the $1880 \mathrm{~s}$, production shifted from iron to steel nails.

By the 1880 s, wire nails became more prevalent, with the first US patent for wire nails granted in 1877. Initially, wire nails were made from iron wire. By the late 1880 s and early 1890s, wire nails were being produced from stronger steel wire in sizable quantities as the technology for producing steel improved. Wire nails are made by cutting each nail from a coil of drawn wire, sharpening a tip, and adding a head. Wire nails remain the dominant type used for most purposes today, though cut nails are still used for some specialty applications such as period architecture and furniture. ${ }^{2}$ For wire nails, the manufacturing technology also improved considerably in the decades after the 1880 s. Today, a significant part of nailmaking has become continuous-process manufacturing, with large wire rolls fed into a machine that automatically transforms that wire into finished nails.

Hand-forged and cut nails look rather similar and, indeed, they have similar "holding power" (or resistance to being withdrawn after being hammered in). One advantage of hand-

\footnotetext{
${ }^{2}$ One US manufacturer-Tremont Nail Company in Wareham, Massachusetts — still makes cut nails, in some cases using vintage machinery with some components dating back to the early $19^{\text {th }}$ century. (Based on a factory tour and conversation with Gary Anderson in early 2020.)
} 
forged nails over early machine cut nails is that forged nails could be "clinched": that is, the tip of the nail that extended through the pieces of material being joined could be bent over, or clinched, thereby increasing the holding power of the nail. Early machine cut nails had the grain of the metal running perpendicular to the length of the nail, and cut nails would break if an effort were made to clinch them. Later, cut nails were made with the grain of the metal running parallel to the length of the nail, and these cut nails could be clinched. Wire nails have considerably less holding power than forged or cut nails, but, because each nail is lighter, shipping costs per nail were less. The basic wire nail has changed relatively little since the 1890 s, with the graphic in late $19^{\text {th }}$ century Sears catalogues depicting a nail that looks much like one that could be purchased at Home Depot today.

Even for a run-of-the-mill item like nails, the changes in manufacturing processes were a big deal. Prior to the industrial revolution nails were produced one at a time by a blacksmith, and, according to Rybczynski (2000, p. 70-71), it took about a minute for a skilled blacksmith or nailsmith to produce a single hand-forged nail. Adam Smith (1776) highlighted early process improvements for pin manufacturing, and many of the same developments would have been applied to nail manufacturing as well. Changes since then have been more dramatic. Currently, a typical nail-making machine with a footprint of about three square feet can produce 300 to 450 wire nails in a minute while the newest machines can produce 2000 nails per minute. Assume 500 nails per minute, on average, and that a worker can operate seven machines at once. ${ }^{3}$ Thus, the number of nails produced per minute of worker time has increased by a factor of 3500 times since the era of hand-forged nails.

\footnotetext{
${ }^{3}$ Roelif Loveland, President of Maze Nails, provided information in a January 2020 email on the number of nails per minute made by a typical nail-making machine as well as the number made by the latest machines. In addition, he reported that a worker can operate seven machines at once.
} 
These shifts from hand-forged to cut to wire nails track with broader changes across the US manufacturing sector described by Goldin and Katz (1998). They highlighted the evolution from artisanal to factory to continuous-process production technologies, and nails provide a canonical example of that transformation.

The rapid price declines for nails documented in this paper also affected economic activity more broadly in the $19^{\text {th }}$ and early $20^{\text {th }}$ centuries. Those effects were especially pronounced in the construction industry (including railroad beds and fences) during a time when construction represented a larger share of economic activity than it does today: for example, residential and nonresidential construction amounted to 16 percent of nominal GDP in 1839 (Gallman 1966), compared with about 63/4 percent in 2019. One particularly important transformation within construction is that the drop in prices of nails enabled "balloon-frame construction" to develop in the $19^{\text {th }}$ century as a considerably lower-cost style of construction than the long-used post-and-beam approach (Jackson 1987). Balloon-frame construction-in which a building's walls are made up of dimensional-lumber studs (typically 2" x 4" today) that carry the weight of the structure-use many nails and became feasible only after the relative price of nails had fallen far enough. Outside of construction, other downstream sectors benefitting from price declines for nails include furniture, wooden containers and boxes, and many other products made from wood.

Beyond reductions in cost of production, the variety of nails produced has expanded significantly over the years, including nails made from specialized materials for particular applications, nails made with coatings to prevent rust, and nails made with rings around the shank to increase holding power. Indeed, the website of Maze nails, one of a handful of current 
American nail manufacturers, lists 110 distinct varieties of nails, not counting different sizes and colors of the same type of nail. ${ }^{4}$

\section{Nail Prices}

\section{Raw Nominal Price Data}

Figure 2 plots the raw data on the nominal price of nails in cents per pound; nearly all the price quotes I found for nails were on a price per pound basis. In the figure, different colors capture the different "regimes" of data. The green segment refers to prices from Beveridge (1939) for nails in the United Kingdom from 1695 to 1792. Beveridge collected these prices from log books of Greenwich Hospital. Given the time period, these quotes must have been for hand-forged nails, and the quotes cover a wide range of sizes, with prices provided in UK shillings per 12 pounds of nails. I converted these prices to US dollars using an exchange rate from UK pounds to US dollars for $1792 .{ }^{5}$ Thus, before 1792, these prices are capturing movements in prices in the United Kingdom, indexed to the 1792 value in cents per pound.

The blue segment in Figure 2 captures prices from Cole (1938) for the period from 1784 to 1813 . These data represent wholesale prices in the Philadelphia market. ${ }^{6}$ The type of nail is not specified, but, given the time period, these quotes probably cover a mix of hand-forged and

\footnotetext{
${ }^{4}$ Catalog available at https://www.mazenails.com/assets/pdf/maze-nails-price-list-catalog.pdf. The list of nail varieties is on page 4 of the 2020 catalog.

${ }^{5}$ The exchange rate used for 1792 is $\$ 4.47$ per U.K. pound sterling, downloaded from Measuring Worth website (2011).

${ }^{6}$ The Appendix provides details on the sources from which all of the prices in Figure 2 were drawn. As highlighted in the text, the price quotes from nails are taken from disparate sources, often reflecting prices in major cities that may or may not be representative of nail prices in other locations or purchased through other distribution channels. Overcoming this challenge would be difficult given available data. That said, Rothenberg (1979) found that movements in prices received by farmers for agricultural products in rural Massachusetts were similar to price movements for those products in Boston and New York City.
} 
cut nails. I refer to this segment of data as "mixed." The quotes in Cole are for various size lots, and they were all converted to cents per pound of nails.

The red segment covers machine-cut nails from 1814 to 1890 . These data are from Cole from 1814 to 1828 and from various other sources in the later part of the period. The price quotes cover wholesale prices for New York City through 1849 and prices posted by a Pennsylvania nail manufacturer through 1890. The quotes are for dollars per hundred pounds and were converted to cents per pound.

The black segment in Figure 2 covers the period from 1890 to the present and refers to wire nails. This segment incorporates data from the Bureau of Labor Statistics, reflecting a number of different reports for the earlier periods and Producer Price Indexes for more recent years. In the data, the quotes are for different varieties of nails and are quoted for lots of various sizes. All of these quotes were converted to cents per pound.

The choice of breakpoints in price quotes across the different types of nails is largely driven by data availability. That said, the switchovers to cut nails in 1814 and to wire nails in 1890 are consistent with what historical archaeologists characterize as the eras in which each type of nail was prominent (for example, as described in Wells 1998, Figure 8).

At the data breakpoints, as can be seen in Figure 2, there are some discontinuities in prices. In the late 1700s, the series for forged nails in the United Kingdom (shown in green) is below the series for "mixed" nails (shown in blue) in the United States. This gap could reflect any of a number of factors. Perhaps nails were produced more cheaply in the United Kingdom in this period. However, shipping nails was expensive so if shipping charges were added to the U.K. prices, they might look more like the higher US prices during this period. In addition, the descriptions of the nails for which prices were collected often are limited, so there likely are 
differences in what is being priced. The break after 1813 reflects the data source which began explicitly pricing cut nails starting 1814 . The implied jump in price in that year is not so surprising given that it occurred during the War of 1812, when many commodity prices rose. The other interesting overlap is that between the series for cut nails (red) and wire nails (black). It appears that wire nails were more expensive, raising the question of why buyers shifted to wire nails, particularly given their less impressive holding power. The resolution of this puzzle is discussed in the section below on quality adjustment.

An Alternative Price Series since 1897

As a check on the nail prices from the US Bureau of Labor Statistics covering the period since the late $19^{\text {th }}$ century, I also collected prices for 2" nails from Sears catalogs. These quotes extend from 1897 to 1960, the last year the Sears catalog included steel wire nails in a variety of sizes. One appeal of the Sears prices is that it is straightforward to compare like to like by pricing the same nail over time. For example, it is possible to track the price of 2" nails-that is, size $6 \mathrm{~d}$ - over this period, where a number followed by the letter $\mathrm{d}$ is a standard for nail sizing. Moreover, economists have a long tradition of using Sears catalogs (and those from other retailers) to track prices over time--including work by Rees (1961) and Gordon (2008)—so these catalogs are a natural source to use as a check on the government price data.

These Sears prices are plotted as the dashed black line in Figure 2.7 Starting in 1897, these prices are nearly indistinguishable from the US Bureau of Labor Statistics prices shown by the solid line. However, subsequently, the Sears series starts to rise more rapidly than does the Bureau of Labor Statistics series and by 1960 the Sears price is 70 percent higher the other price

\footnotetext{
${ }^{7}$ The Sears prices of nails are plotted on a cents per pound basis to match the units of the other raw series shown in Figure 2. As noted below, these prices can be readily converted to a cents/nail basis.
} 
(16.4 versus 9.6 cents). While it is difficult to ascertain definitively the source of this growing gap, a likely factor is a shifting wholesale/retail margin at Sears. The price quotes forming the basis for my preferred price series are producer prices. The Sears price is, technically, a retail price, though in the late 1800s and the first part of the 1900s, Sears sold nails in large volumes (100-pound kegs) and sold them directly to homebuilders (inferred from the advertising copy in the catalogs). In the more recent period, it appears that the Sears catalog was catering almost exclusively to small-scale retail purchasers of nails. In particular, starting in the mid-1930s, Sears began quoting prices for one-pound packages and in the early 1940s began quoting prices for five-pound packages; by this time Sears no longer quoted prices for 100-pound kegs of nails in their catalog.

These changes support the view that Sears gradually shifted from being more of a wholesaler to more of a retailer in the market for nails. Such a shift would be consistent with the more rapid increase in Sears' prices relative to the Bureau of Labor Statistics prices and would suggest that Sears prices after about 1930 may not be so useful for tracking producer or wholesale prices of nails. This gap also emphasizes the importance of care in choosing what price of a product to track over long spans of time. ${ }^{8}$

\section{Real Prices}

The real price of nails over time is constructed by deflating the nominal nail price index with an index of consumer prices. I construct a consumer price index back to 1695 by using ratio splices to link together series for the United Kingdom retail price index from 1695-1784, the US

\footnotetext{
${ }^{8}$ I suspect that this issue of shifting wholesale/retail margins could affect other products in the Sears catalogs as well. In a different context, Gordon (2008) found evidence for a later period that prices for apparel in Sears catalog increased relative to the Consumer Price Index as Sears was increasingly undercut on prices by new competitors such as Target and Walmart. My conjecture about margins, along with Gordon's results, suggest that researchers using catalog prices may need to be mindful of what catalog prices represent.
} 
Consumer Price Index for 1784-1928, and the chain price index for Personal Consumption Expenditures from the US Bureau of Economic Analysis for 1929-2018. Of course, as Gordon (2008), Nordhaus (1997), and many others have noted, comparisons of price indexes over very long spans of time raise a host of difficult issues. Nonetheless, it seems more relevant to focus on real prices - despite the inherent limitations — rather than nominal prices, particularly given the central interest in the prices of nails relative to those of other goods and services.

Real prices of nails, relative to the consumer prices, are shown in Figure 3 on a cents-perpound basis from 1695-2018 by the dashed line segments. On this basis, without any adjustment for quality changes, the real price of nails was relatively stable from 1695 through the early 1800s (at least compared with the large decline that followed) with a peak in the mid-1700s. Then, during the 1800s, the real price fell substantially through the 1930 s before rising, on balance, over subsequent decades.

\section{Quality Adjustment}

Ideally, price indexes are constructed on a quality adjusted basis, so that price comparisons over time are like-to-like. For example, directly comparing prices of a car today to a Model T in 1908 would be problematic because the quality of the vehicles is so different so that it would not represent, without some adjustments, a like-to-like comparison. Quality-adjusting prices of nails is much easier because, as noted above, nails have changed very little over the centuries. In my calculations, just two adjustments are made to construct a quality-adjusted price index for nails.

First, nail prices are adjusted so as to track, as well as possible, the same size nail over time. The series on nail prices on a cents-per-pound basis does not price a homogenous product, 
but rather is conflating prices of nails of many different sizes. To standardize the size of nails in the index, I convert everything to be as equivalent as possible to a 2" (size 6d) nail. For the earlier periods before nails sizes were standardized, I also standardize on 2" nails. To do this, I convert pounds of nails to the number of 2" nails using an estimate of the number of 2" nails per pound. As detailed in the appendix, I use a count of 85 nails per pound for both forged and cut nails for the period spanning 1695 to 1889 based on an average of counts from multiple sources. Wire nails are considerably thinner, and as the quotes switch to wire nails in 1890 , the count jumps to 150 nails per pound for 2" nails in that year. The count briefly increases further to 181 during World War II when nails available to the public became thinner, presumably to conserve essential war materials. After the war, the count dropped back to 168, where it has remained since. With these counts, I convert prices in real cents per pound to real cents per nail, and the solid line segments in Figure 3 show these prices.

One key difference is evident between the two lines in Figure 3 as a result of this quality adjustment. Prices fell by a larger multiple on a per nail basis than on a per pound basis. In particular, note what happened around the period of transition in price quotes in 1890 from cut nails to wire nails. On a per pound basis, wire nails look more expensive than cut nails, but on a per nail basis, wire nails look less expensive than cut nails. The reason for this difference is the higher count of wire nails per pound than of forged or cut nails. Temin (1964) pointed out that the lighter weight of wire nails meant lower shipping costs per nail, enhancing the attractiveness of wire nails. This discussion highlights the importance, for the purposes of price measurement, of being as precise as possible about the product being priced. 
The second adjustment accounts for differences in other characteristics of hand-forged, cut, and wire nails. Key differences include "holding power" and shipping costs. ${ }^{9}$

Regarding holding power, wire nails have less holding power than cut or forged nails. This outcome occurs primarily because the cross section of a cut or forged nails is rectangular and tapered compared with the round and untapered cross section of a wire nail. The greater holding power comes from the wedging action arising from the shape of the cut nails when pounded into wood. In the world of wood engineering, these differences in holding power have been measured, and the literature suggests that cut nails have about twice the holding power of wire nail. The prices plotted in Figure 3 could be adjusted explicitly for differences in holding power. However, for many applications, the smaller holding power of wire nails is perfectly sufficient so that the greater holding power of cut nails would be unnecessary and may not be valued as highly as would be suggested by an explicit adjustment for holding power.

Shipping costs are another characteristic that would be important to some buyers. For example, the 1897 Sears catalog indicates that shipping costs for a 100-pound keg of nails from Chicago to Boston amounted to about 20 percent of the price of the nails. Given the greater number of wire nails that would be in a keg compared with the number of cut nails, shipping costs per nail would have been considerably lower for wire nails than for cut nails. Again, with some additional data and calculation, the prices in Figure 3 could be explicitly adjusted for differences in shipping costs.

How best to account for identifiable differences in holding power, shipping costs, and any other relevant characteristics of different types of nails? One modern approach is to construct a so-called hedonic price index that would use statistical techniques to explicitly account for all

\footnotetext{
${ }^{9}$ The Appendix provides some additional information on the holding power of cut and wire nails, as well as some additional analysis of shipping costs.
} 
relevant characteristics of nails and for how the marketplace valued those characteristics. Data limitations make that impossible in this case. Thus, I use another common technique, a matchedmodel procedure. This methodology links the cents-per-nail prices in Figure 3 across the switchover points from one type of nail to another; this linking will accurately adjust for quality change to the extent that the price/performance ratio for nails was equalized by the market in periods when multiple types of nails were available. This approach is a sensible and widely used methodology to construct a consistent price index that adjusts for changes in quality over time so that like can be compared to like given available data. Specifically, I start with the prices for the most recent period (the black segment for wire nails), and then link backwards. In each of the crossover years $(1890,1814$, and 1784), I use the price from the more recent type of nail and link and extend backwards from that year using percent changes in prices for the earlier type of nails in the earlier years.

The matched-model price series is plotted in Figure 4. It shows that real prices of nails fell by a factor of about 10 from the late-1700s to its low point in the middle of the $20^{\text {th }}$ century, amounting to a 1.6 percent annual average rate of decline from 1792 to 1930 . Declines in real prices during this period were uneven, with especially rapid declines during two periods: from the early 1820 s to 1860 and from the early 1880 s through about 1930 . Since the middle of the $20^{\text {th }}$ century, real prices have risen considerably on balance. 


\section{What Accounted for Changes in the Real Price of Nails?}

Over long spans of time, changes in nail prices, as for any product, should largely depend on changes in the cost of inputs and on advances in the production technology (very roughly captured through multifactor productivity). Economists capture these relationships through decompositions that breakdown changes in prices of a product into its proximate sources. While such decompositions are not causal in any sense, they do provide valuable insights; for example, quantifying linkages between changes in prices of nails and changes in the prices of key inputs such as iron or steel.

The basic setup for this decomposition begins with a conventional growth accounting relationship that decomposes quantities. In a textbook version, growth in output (value-added) is broken down into contributions from capital, labor, and multifactor productivity. Typical assumptions in this setup include a Cobb-Douglas production function with constant returns to scale (factor shares summing to one) and perfect competition in input and output markets. Multifactor productivity captures all elements other than inputs that affect output and often is taken by macroeconomists to be a rough measure of the state of technology; that is, multifactor productivity rises if it is possible to produce more output from the same quantity of inputs. With these assumptions, the growth in output equals a weighted average of growth in capital and labor (with the weights equal to factor shares) plus the growth in multifactor productivity.

For the purpose here, a more complex version of this relationship - the KLEMS variant of growth accounting as described in Jorgenson, Fukao, and Timmer (2016) - is more useful. This approach decomposes growth in gross output (Y) and, in addition to capital (K) and labor (L) inputs, includes energy inputs (E), materials (M), and purchases services (S). Purchased services include any services purchased from outside the business, such as repair services. The full relationship, including multifactor productivity is given by: 


$$
\dot{y}=\alpha_{K} \dot{k}+\alpha_{L} \dot{l}+\alpha_{E} \dot{e}+\alpha_{M} \dot{m}+\left(1-\alpha_{K}-\alpha_{L}-\alpha_{E}-\alpha_{M}\right) \dot{s}+\dot{m} \dot{p}
$$

where lower case variables with dots over them represent growth rates (log differences) of inputs and the $\alpha^{\prime} s$ are the factor shares. In this setup, both the growth rates of inputs and the factor shares vary year-to-year.

Because I am focusing on changes in prices rather than quantities, I turn to the dual representation of the production function. While the production function focuses on the relationship between the quantities of output and inputs, the dual is a corresponding relationship between the price of output and the cost of inputs. In percent change terms the dual relationship is:

$$
\dot{p}=\alpha_{K} \dot{r c}+\alpha_{L} \dot{w}+\alpha_{E} \dot{p_{E}}+\alpha_{M} \dot{p_{M}}+\left(1-\alpha_{K}-\alpha_{L}-\alpha_{E}-\alpha_{M}\right) \dot{p_{S}}-\dot{m f p}
$$

where $\mathrm{P}$ is the price of nails plotted in Figure 4, RC is the rental costs of capital, $\mathrm{W}$ is wages, $\mathrm{P}_{\mathrm{E}}$ is the price of energy, and $\mathrm{P}_{\mathrm{M}}$ is the price of materials, and $\mathrm{P}_{\mathrm{S}}$ is the price of purchased services, respectively, with all prices measured in real terms. Again, lower case variables with dots over them represent growth rates (log differences) of inputs and the $\alpha^{\prime} s$ are the factor shares. Notice that growth of multifactor productivity enters the dual equation with a negative sign. When focusing on quantities, gains in multifactor productivity raise output; when focusing on prices, gains in multifactor productivity hold down prices relative to the contributions of factor costs. In short, this formulation says that changes in the price of nails reflects a weighted average of 
changes in input (factor) prices using factor shares as weights, with an adjustment for multifactor productivity growth.

To empirically implement equation 2 , I proceeded as follows. The series on qualityadjusted nail prices from figure 4 is used for the left-hand side. For the right-hand side terms for each input, I compiled an annual dataset on factor prices and factor shares for capital, labor, energy, materials, and services as described below. Finally, in this type of analysis, growth in multifactor productivity is calculated as a residual by subtracting the terms for changes in input costs from changes in prices. As noted above, multifactor productivity captures all elements other than changes in factor prices or shares that affect that the price of nails, such as rearranging the physical layout of production once electricity became widely used as power source.

\section{Data on Factor Prices}

For factor prices, I assembled annual data back to 1790 on the rental cost of capital, wages, the price of energy as likely used in manufacturing, the price of steel and iron for earlier

years, and an estimate of the price of purchased services. I used 1790 as the initial year because that is when the wage series started. (Briefly, I used data from various sources, including the Bureau of Labor Statistics, Gallman and Rhode (2019), measuringworth.com (2020), the NBER MacroHistory database, Temin (1964), and Warren and Pearson (1933). Each factor price was converted to real (2012 \$) using the index for consumer prices that was used to calculate real nail prices. Additional details on sources and data construction are described in the Appendix.

Figure 5 plots the resulting real factor prices for each input with each price indexed to 100 in 1790 . Real wages rose substantially from $1790-2018$, as did the real price of purchased services. (No surprise on that purchased services rose in a similar way to services, given that 
wages were used as an extrapolator for costs of services prior to 1949.) The real rental price of capital was relatively flat from 1790 until about 1900, and then moved lower through 2018 . The real price of energy followed a similar trajectory to that of capital, though it declined more rapidly during the $20^{\text {th }}$ century until the early 1970 s energy crisis after which it moved higher. The real price of materials fell through about 1950 and then began moving higher.

These long spans of factor prices rely on solid research by statistical agencies and economic historians. That being said, they undoubtedly are measured with some error. Again, linking together price statistics over long spans of time can miss the benefits of more revolutionary changes in inputs. For example, the benefits of the switch from water-power to steam-power likely are missed in my methodology, given that fuel prices were used to extend back into the period when water was a principal power source. The linking methodology also may miss benefits of the switch from steam to electric power. Moreover, I pulled data from many different sources, likely creating inconsistencies in the definitions and data collection procedures used.

One area of particular concern is the rental price of capital, because the capital stock deflators that I rely on were not constructed with the attention to quality adjustment that is typical for many types of capital in a modern price measurement framework. Nonetheless, these factor prices capture important trends over time. In addition, the price decomposition I implement relies only on growth rates (log differences) in these factor prices, so some inconsistencies in levels will be washed out. Finally, as shown by the sensitivity analysis described below, even substantial allowances for measurement error in the cost of capital would not alter the basic story that emerges from my analysis. 


\section{Data on Factor Shares}

For factor shares for capital, labor, energy, materials, and purchased services, I also had to rely on a range of sources, including a KLEMS decomposition for fabricated metal products since 1949 published by the Bureau of Labor Statistics; the Hand and Machine Labor study published in 1898 that compared machine production for many products in 1897 to hand production for the same products in $1813^{10}$; and the Bateman, Weiss, and Atack extracts from the 1850 and 1870 Census of Manufactures as described in Atack and Bateman (1999). From these sources, I obtained annual factor shares from 1949-2018 and shares for 1813, 1850, 1870, and 1897. For the intervening years, I linearly interpolated shares. For the years prior to 1813 , I used the 1813 shares. Because I am using a decomposition into five factors (plus multifactor productivity), the labor and capital shares will not be the familiar $2 / 3$ and $1 / 3$, although the five factor shares still sum to unity under the maintained assumption of constant returns to scale.

Estimating factor shares for 1850 and 1870 from the Bateman, Weiss, and Atack Census extracts has not been done often and is not entirely straightforward so a brief explanation here is warranted, with details of this and other data sources and procedures described in the Appendix. ${ }^{11}$ For 1850 and 1870, the extracts provide firm-level accounting information for a sample of firms in those years. I identified the firms in the extracts for which nails were the dominant output: seven firms in 1850 (three hand-powered, three water-powered, and one steampowered) and four firms in 1870 (three steam-powered and one water-powered). For each firm, the extract provided figures for the value of output, the wage bill, the cost of energy inputs, and

\footnotetext{
${ }^{10}$ For background on the Hand and Machine Labor study, see Atack, Margo, and Rhode (2019, 2020). They recently digitized the voluminous information in that study, making it much more widely accessible to researchers. Although not directly related to the measurement of factor shares, see Margo (2015) for a discussion of likely measurement error for the labor input of smaller firms relative to larger firms.

${ }^{11}$ One other paper that used these data to identify key aspects of production processes is Margo and Atack's (2019) paper on US blacksmithing from 1850-1870.
} 
the cost of materials inputs. From these, I could calculate factor shares for labor, energy, and materials. The extract also provided an estimate of firm "capital," although it is not entirely clear what is included in that figure. Nonetheless, I used that number and the user cost of capital formula (along with some assumptions about components of the formula) to estimate the factor share for capital. For purchased services, I calculated the factor share as a residual, subtracting the value of all other inputs from the value of nails produced. The numbers used for my decomposition are the unweighted average factor shares across the seven firms in 1850 and across the four firms in 1870 .

Figure 6 plots the estimates of factor shares from 1790-2018. Two observations fall out immediately from this figure. First, the capital intensity of nail production rises over the period, with capital's share rising steadily over time, from a low between 3 and 4 percent at the beginning of the sample to about 15 percent by 2018. Second, the energy share remains low throughout the sample, though it is lowest in the earliest years. Other observations are more subtle, given the ups and downs of factor shares. Labor intensity was relatively high early in the sample during the period of hand production (about 34 percent in 1790). As nail manufacturing began to become mechanized, the share fell to about 25 percent in 1850 . The share then rose over the next 100 years to reach just above 40 percent in the early 1950 s. Since then, my estimate of the labor share drops back to about 30 percent by 2018, likely owing to increased mechanization as reflected by the rise in the capital share during this period. The materials share generally increases and then falls back, rising from around 36 percent in 1790 to about 50 percent by 1870 , drifting lower to about 40 percent by the late 1940 s, and then fluctuating around that value through the end of the sample. Finally, the purchased services share generally declines and then increases part way back; specifically, it falls from around 25 percent early in the sample 
to around 10 percent in the 1980 s before rising back up to about 15 percent by the end of the sample.

In my view, the factor share estimates are the weakest element of the price decomposition, given the sparseness of years for which I obtained estimates, the range of very different sources and methodologies, and the incompleteness of data even for the years for which I obtained estimates. Indeed, one could argue that we do not know enough about early factor shares to draw confident conclusions. However, the sensitivity check described below suggests that any plausible measurement error in factor shares would not significantly affect the conclusions drawn from the decomposition of proximate sources of changes in real prices of nails. In addition, my estimates for factor shares are not that different from those of other researchers using different sources, again as described in the Appendix.

\section{What Accounted for Price Changes?}

With data on factor prices and shares in hand, I can calculate the price term on the lefthand side and the term for each input on the right-hand side of the price decomposition for each year, estimating multifactor productivity growth as a residual. For these annual estimates, I follow usual practice in the growth accounting literature in which the factor shares used in the decomposition are the average of shares for the two years covered by each annual percent change in a factor price; for example, the factor shares entering the price equation for, say, 1872 are the averages of the annual factor shares for 1871 and 1872. Although I calculate the decomposition for each year, I only report averages over longer spans of time, given the short-run volatility in markups, tariffs, taxes, and other factors.

Table 1 reports the price decomposition for nails. The selected periods shown correspond to eras I identified in trends for real prices of nails: the modest declines from the late $18^{\text {th }}$ century 
through about 1820, the first wave of very rapid declines that came with increasing mechanization through 1860 , the flattening out during the next two decades, the second wave of very rapid price declines between 1881 and 1930, and then the substantial increases in real prices from the 1930s through the end of the sample in 2018.

Looking across periods, the most interesting and important result in the decomposition is the large contribution of multifactor productivity. In the early period (1791-1820) when real nail prices declined about 0.4 percent a year, rapid advances in multifactor productivity pulled down nail prices by an average of 1.5 percentage points per year. (Recall that increases in multifactor productivity hold down nail prices.) The improvement in multifactor productivity was even more substantial during the first (1821-1860) and second (1881-1930) waves of rapid decline in real nail prices, with multifactor productivity growth holding down the annual average rate of change of real prices by 2.6 and 2.3 percentage points in these periods, respectively. ${ }^{12}$ Then, in more recent decades, declines in multifactor productivity growth accounted for nearly 0.5 percentage point per year of the increase in real nail prices.

The very large role of multifactor productivity growth during the two waves of rapid price declines in real nail prices suggests that developments other than changes in input costs or factor shares contributed importantly to declining nail prices. Interpreting multifactor productivity can be difficult given that it is calculated as a residual so it is impossible to know exactly what accounted for a given change. Moreover, any measurement error in factor prices or shares would be reflected in multifactor productivity. That being said, other research highlights one important explanation for the big role of multifactor productivity. For the $19^{\text {th }}$ century,

\footnotetext{
${ }^{12}$ The decomposition used here abstracts from shifts in the complementarity of capital to skilled and unskilled labor as the technology of nail-making evolved, a factor highlighted by Goldin and Katz (1998). To the extent that such shifts are not accounted for by input prices or shares, they will be reflected in the multifactor productivity term in the decomposition.
} 
Atack, Margo, and Rhode (2019, 2020), using their digitized version of the Hand and Machine Labor study, provide evidence that mechanization per se accounted for only about one-third of the productivity advance in manufacturing between 1813 and 1897. In their analysis, the balance of $19^{\text {th }}$ century productivity advance reflected other factors, such as the increasing specialization of labor, which would be captured in multifactor productivity.

Similarly, the outsized role of multifactor productivity likely reflects, at least in part, the story told by David (1990) for the transition from steam to electric power early in the $20^{\text {th }}$ century. In particular, he highlights the important role of reorganization of manufacturing processes in boosting labor productivity, a factor that also would show up as multifactor productivity growth.

Materials prices also contribute importantly to declines in real nail prices, especially during the first and second wave of rapid price declines. Specifically, falling real materials prices pull down real nail prices by an average of about 0.75 and 1.3 percentage points per year in 1821-1860 and 1881-1930, respectively. These rapid price declines in materials prices - iron in the earlier period and steel in the latter period-likely reflect the dramatic advances in the manufacture of those inputs. This pattern of declining materials prices reversed more recently, consistent with the general upturn in commodity prices after 1950 (as documented by Jacks 2013). The upturn in materials prices in the decades after 1930 contributed about 0.3 percentage points per year to the average annual increase in real nail prices.

Among other factors, changes in the rental price of capital account for relatively little of the change in the real prices in any period, reflecting the modest changes in the price of capital and capital's relatively small factor share. This result may seem surprising, but it does fit with the story that there was more than just mechanization to the changes in nail manufacturing. Real 
wages make a consistent and noticeable positive contribution to nail prices ranging from about 0.3 to 0.8 percentage point per year on average, partially offsetting other sources that pushed down nail prices in some periods. Interestingly, declines in the price of energy make only very modest contributions to declines in the real price of nails through 1930 and also very little contribution to the upturn in nail prices in more recent decades. The factor share of energy is sufficiently small so that even substantial swings in energy prices do not (and cannot) account for much of the movement in real nail prices.

\section{Sensitivity Analysis and Measurement Error}

As noted, the estimates of factor shares are based on incomplete source data and so could well be subject to measurement error, especially for periods prior to 1949 (the first year for which more detailed data from the Bureau of Labor Statistics on shares are available). In addition, concerns could be raised that the price deflator for capital in the earlier periods did not fully account for quality improvements in successive vintages of nailmaking machinery. To assess the effect of some of the more plausible measurement errors, I did two sensitivity analyses.

First, I held factor shares prior to 1949 fixed at their 1949 levels and recalculated the decomposition of price changes. In this "fixed-share" scenario, the overall pattern of contributions is very similar to that in the decomposition reported above with my estimates of factor shares. This result suggests that measurement error in factor shares would likely have little effect on the conclusions drawn from the decomposition of price changes.

Second, I considered an alternative scenario for capital prices in which the deflator for capital falls more rapidly than in the decomposition above to capture the possibility that 
significant improvements in capital were not reflected in its deflator. If that were the case, then the contribution of the rental cost of capital to price declines for nails would be larger than the negligible effect in the numbers reported above and the contribution of multifactor productivity to price declines—which is calculated as a residual—would be smaller. That being said, even significant measurement error in the price deflator for capital would not affect the overall story. Between 1790 and 1948, the real rental price of capital used in the decomposition declined at an average annual rate of 0.29 percent. (By comparison, the average rate of decline of this variable from 1949-2018 is 0.32 percent.) Suppose that the true real rental price of capital declined 4 percentage points faster per year than is reflected in the data I relied on, a change that would represent a massive reassessment of deflators for capital in the $19^{\text {th }}$ century. With capital's factor share averaging in the neighborhood 10 percent, adopting this alternative cost of capital would make capital's contribution to declining real nail prices larger by 0.4 percentage point $(=4 \mathrm{x}$ 0.10) a year with an offsetting reduction in the amount by which multifactor productivity growth held down nail prices. While certainly noticeable, this shift is modest enough to suggest that possible measurement error in the price deflator for capital is unlikely to change the overall story dramatically.

What Accounted for the Increases in Real Nail Prices Since the Mid-20 th Century?

The decomposition of real price changes suggests that the increases in nail prices since the 1930s primarily reflects two factors: the upturn in materials costs after decades of declines and a decline in multifactor productivity after sizable increases in earlier periods. (Again, recall that in this price-based decomposition, increases in multifactor productivity hold down prices, while declines in multifactor productivity boost prices.) Real wages also rose in this period and 
made a positive contribution to the change in nail prices since the mid- $20^{\text {th }}$ century, although that positive contribution is not so different from that in earlier periods. The increase in steel prices amidst a more general rise in commodity prices is straightforward to understand. However, the decline in multifactor productivity is puzzling. Did the ability of nail manufacturers to organize production really go backwards? This question raises the possibility that other factors, not reflected in the earlier decomposition, may also have played a role. Possibilities along these lines include the difficulty of tracking prices of US produced basic nails amidst a shift in domestic production toward specialty nails in the wake of import competition for basic nails.

Some straightforward calculations show that the import share for nails (imports/domestic absorption) began a dramatic uptrend in the 1950 s, rising to about 70 percent by the 1980 s before dropping back somewhat. This increase in imports came earlier than for many other manufactured goods, likely reflecting that by 1950 the technology for producing basic wire nails was widely and well understood.

Several pieces of evidence suggest that this increase in imports led domestic producers to shift to more specialized, higher-value products. First, the US Bureau of Labor Statistics discontinued specific series for prices of domestically-produced nails after 1998 and shifted to pricing a broader category of steel hardware, presumably because the agency no longer could find enough price quotes for domestically produced basic nails. Second, a current US nail manufacturer confirmed the shift in product mix; specifically, Maze nails, one of the few remaining US producers of nails, now produces mostly specialized nails. In addition, by the 2000s the U.S. military was having difficulty finding domestically-produced basic hardware as noted in Mandel (2011). 
The final evidence supporting the view that domestically-produced nails represented a different product mix than imported nails comes from a comparison of prices of imported and domestically-produced nails. Relevant import price data are available starting in 1974, though consistent with the earlier theme prices are available only for broader and broader categories over time. (From 1974-2005, the available series covers "nails, screws, nuts, bolts, and rivets of iron, steel, copper or aluminum"; from 2005-2010, the series reports prices for "hardware manufacturing"; and since 2010 it covers the even broader category of "fabricated metal products.") On this measure, real import prices fell nearly 60 percent from 1974 to 2018. During this time period, the matched-model index for prices of domestically-produced nails increased, on balance. This sharp divergence in the trajectory of prices suggests that the import price series and the Producer Price Index for domestically-produced items were tracking different products. (Additional information on issues related to nail imports and prices is provided in the Appendix.)

Taken together, this evidence suggests that in recent decades, my series on real nail prices was no longer tracking the 2" nail that I standardized on in earlier periods. While I do not have access to the underlying detail for the relevant Producer Price Index series, it is easy to imagine scenarios in which prices of specialty nails would rise faster than those for basic nails that were now imported in significant quantities. If so, then that shifting product mix also contributed to the run-up in recent decades in the real nail prices reported in this paper.

\section{Nail Guns and the Price of Installed Nails}

Nail guns, which first became widely available in the early 1980s, are an important innovation in the construction industry, and they had sizable effects on the all-in "installed" price of a nail. Indeed, nail guns raise the question of what nail-related product should be priced. If it 
is an individual nail, then nail guns can be regarded as a distinct piece of complementary capital equipment; however, if the product to be priced is an installed nail, then nail guns should be considered an integral part of the process of installing nails. An all-in price for installed nails would include materials (the nails), capital costs (hammer v. nail gun), labor costs, shipping, and everything else. Although I have not calculated an all-in price across all years, the following illustrative example highlights that nail guns are a big deal.

In mid-2020 on Amazon.com, a high-quality pneumatic nail gun that shoots 2" nails could be purchased for $\$ 247$ and a small compressor and air hose for $\$ 170$. Packs of nails for the gun are about $\$ 75$ per 5000 nails — about 1.5 cents per nail and about twice the price of the same size nail not packed in in strips for a nail gun. In contrast, a standard claw hammer costs about $\$ 16 .{ }^{13}$ For illustrative purposes, assume that a nail gun and compressor last six years in commercial applications and experiences straight-line depreciation over that period (assume the same for the hammer). Further, assume that the hourly wage for a construction worker is $\$ 25$ per hour, somewhat below what the Bureau of Labor Statistics reported as the average hourly earnings of a construction worker in July 2020, on the assumption that a nail installer is somewhat less skilled than an average construction worker and is paid a bit less. Finally, I assume (based on personal experimentation with a hammer and nail gun) that a worker with a hammer can install six nails per minute and that worker with a nail gun can install 20 nails per minute. With these assumptions, a plausible estimate of the cost per installed nail for a worker using a hammer is 7.7 cents per nail (including the cost of the nail, the cost of capital per nail, and the wage per nail). The cost per installed nail for a worker using a nail gun is 3.6 cents per

\footnotetext{
${ }^{13}$ Prices were pulled from Amazon in August 2020 for a DeWalt DWF83PL framing nailer (\$247), a Bostitch BTFP02012-WPK compressor and 50' air hose (\$170), and a standard fiberglass $16 \mathrm{oz}$. claw hammer.
} 
nail, less than half the cost using a hammer. ${ }^{14}$ This calculation indicates that the advent and diffusion of nail guns offset some of the rise in the price of an installed nail thereby mitigating the upward trajectory of nail prices in recent decades.

\section{Conclusion}

This paper focuses on nails - a basic, non-revolutionary manufactured product whose form has changed relatively little over the last three centuries - and constructs price indexes for nails going back to 1695 . The price of nails fell significantly relative to prices of an overall basket of consumption goods, with the real price of nails falling by a factor of about 10 from the late 1700 s to the middle of the $20^{\text {th }}$ century. A growth-accounting type of decomposition into a weighted average of input costs and multifactor productivity highlights that while falling material prices for iron and steel were important during the two bursts of rapid price drops (1821-1860 and 1881-1930), the most important factor contributing to these rapid price declines was increases in multifactor productivity during the period.

The mid- $20^{\text {th }}$ century represented the end of what could be called the golden age of nail manufacturing that started in the late $18^{\text {th }}$ century. Since then, real prices of domestically produced nails have risen considerably. These increases reflect higher materials prices as well as, likely at least in part, difficulties in tracking prices of basic nails amdist a shift in US production to more specialized and higher-priced products. This shift in the composition of US production occurred in the wake of foreign competition in basic nails as advances in the technology of producing basic nails dwindled. Pushing in the opposite direction, however, the introduction of

\footnotetext{
${ }^{14}$ Additional assumptions are that a full-time worker is employed for 2000 hours a year and that the worker spends 500 hours installing nails and 1500 hours arranging materials and undertaking other tasks; accordingly, the labor cost allocated to installing nails is $\$ 12,500(=\$ 25 \times 500)$. On these assumptions, the worker would install 600,000 nails in a year with a nail gun $(=20 \times 60 \times 500)$ and 180,000 nails with a hammer $(=6 \times 60 \times 500)$.
} 
nails guns in the 1980s offset a part of these price increases by significantly lowering the "all-in" price of an installed nail.

The study of nail prices highlights some of the issues involved in price measurement: the details of what the available data are measuring can be quite important, along with issues of evolving quality, import substitution, and complementary input technologies. Nails also serve as a reflection of some of the key patterns of US manufacturing industries: for example, the idea that technology-affecting factors other than automation were of crucial importance in the $19^{\text {th }}$ century, and how the growth of imports for basic products where the technological frontier was not advancing much have altered the face of US manufacturing since the middle of the $20^{\text {th }}$ century. All told, A focus on the price of nails provides a useful window into economic changes over the past 300 years. 


\section{References}

Adams, William Hampton (2002), "Machine Cut Nails and Wire Nails: American Production and Use for Dating $19^{\text {th }}$-century and Early $20^{\text {th }}$-century Sites," Historical Archaelogoy, 36(4), p. 66-88.

American Iron and Steel Institute (various years), Annual Statistical Reports, Philadelphia in early years, New York in intermediate years, and Washington, D.C. in more recent years, previously the organization was the American Iron and Steel Association.

Atack, Jeremy and Fred Bateman (1999), "Nineteenth-Century U.S. Industrial Development through the Eyes of the Census of Manufactures," Historical Methods, Vol. 32, No. 4, Fall, p. 177-188.

Atack, Jeremy, Robert A. Margo, and Paul W. Rhode (2019), “'Automation' of Manufacturing in the Late Nineteenth Century: The Hand and Machine Labor Study," Journal of Economic Perspectives, Vol. 33, Number 2, Spring, p. 51-70.

Atack, Jeremy, Robert A. Margo, and Paul W. Rhode (2020), "Mechanization Takes Command: Inanimate Power and Labor Productivity in Late Nineteenth Century American Manufacturing," NBER working paper number 27436.

Beveridge, William (1939), Prices and Wages in England from the Twelfth to the Nineteenth Century, Vol. I, Price Tables: Mercantile Era, Longmans, Green, and Co., London.

Cole, Arthur Harrison (1938), Wholesale Commodity Prices in the United States 1700-1861, Harvard University Press, Cambridge, MA.

David, Paul A (1990), "The Dynamo and the Computer: An Historical Perspective on the Modern Productivity Paradox," American Economic Review, Vol. 80, No. 2, pp. 355-361.

French, B.F. (1858), History of the Rise and Progress of the Iron Trade of the United States from 1621 to 1857, Wiley and Halstead, New York.

Gallman, Robert E. (1966), “Gross National Product in the United States, 1834-1909," in Output, Employment, and Productivity in the United States After 1800, Studies in Income and Wealth, Volume 30 by the Conference on Research in Income and Wealth, National Bureau of Economic Research and Columbia University Press, p. 3-90.

Gallman, Robert E. and Paul W. Rhode (2019), Capital in the Nineteenth Century, National Bureau of Economic Research and the University of Chicago Press.

Goldin, Claudia and Lawrence F. Katz (1998), "The Origins of Technology-Skill Complementarity," Quarterly Journal of Economics, Vol. 113, No. 3 (August), pp. 693-732. 
Gordon, Robert J. (2018), "Why has Economic Growth Slowed When Innovation Appears to be Accelerating?" NBER working paper number 24554 (April

Gordon, Robert J. (2008), “Apparel Prices 1914-93 and the Hulten/Bruegel Paradox,” in Price Index Concepts and Measurement, edited by Erwin Diewert, John Greenlees, and Charles Hulten, NBER and University of Chicago Press, p. 85-128.

Jacks, David S. (2013), "From Boom to Bust: A Typology of Real Commodity Prices in the Long Run,” NBER working paper number 18874.

Jackson, Kenneth T. (1987), Crabgrass Frontier, Oxford University Press.

Jorgenson, Dale W., Kyoji Fukao, and Marcel Timmer (2016), The World Economy: Growth or Stagnation, Cambridge University Press.

Lewis, Miles (1998), Australian Building: A Cultural Investigation, Section 8: Metals, pulled on June 29, 2011 from www.mileslewis.com.

Mandel, Michael (2011), "Mandel on Innovation and Growth: Air Force Certifies the Weakness of Domestic Manufacturing," available at innovationandgrowth.wordpress.com/2011/0418/airforce-certifies-the-weakness-of-domestic-manufacturing/.

Margo, Robert A. (2015), "Economies of Scale in Nineteenth Century American Manufacturing Revisited: A Resolution of the Entrepreneurial Labor Input Problem" in Enterprising America: Businesses, Banks, and Credit Markets in Historical Perspective, ed. by William J. Collins and Robert A. Margo, NBER and University of Chicago Press.

Margo, Robert A. and Jeremy Atack (2019), "Gallman revisited: blacksmithing and American manufacturing, 1850-1870," Cliometrica 13, pp. 1-23.

Maze Nails Company, online catalog, available at www.mazenails.com/assets/pdf/maze-nailsprice-list-catalog.pdf.

Measuring Worth (2011), historical exchange rates from www.measuringworth.com/datasets/exchnagepound accessed during May and June 2011.

Measuring Worth (2020) historical price data from www.measuringworth.com/datasets/uscpi accessed July 2020.

New York Times, "Builder of Housing for Middle Class Dies at 93,” June 26, 1999, p. B7.

Nordhaus, William D. (1997), "Do Real Output and Real Wage Measures Capture Reality? The History of Lighting Suggests Not," in Timothy F. Bresnahan and Robert J. Gordon, eds., The Economics of New Goods, Vol. 58, 1997, pp. 29-66. 
Nordhaus, William D. (2007), "Two Centuries of Productivity Growth in Computing," The Journal of Economic History, vol. 67, issue 01, pages 128-159.

Rees, Albert (1961), Real Wages in Manufacturing: 1890-1914, NBER and Princeton University Press.

Rothenberg, Winifred (1979), “A Price Index for Rural Massachusetts, 1750-1855,” The Journal of Economic History, Vol. 39, No. 4, December, pp. 975-1001.

Rybczynski, Witold (2000), One Good Turn: A Natural History of the Screwdriver and the Screw, Scribner, New York.

Smith, Adam (1776), The Wealth of Nations,

Temin, Peter (1964), Iron and Steel in the Nineteenth Century America, MIT Press, Cambridge, Massachusetts.

United States Bureau of the Census (2007, 2012, and 2017), Census of Manufactures, Washington, D.C.

United States Bureau of Labor Statistics (1899), Hand and Machine Labor, $13^{\text {th }}$ Annual Report of the Commission of Labor 1898, Volume 1 (Introduction and Analysis) and Volume 2 (General Table).

United S Department of Labor. 1899. Thirteenth Annual Report of the Commissioner of Labor, 1898: Hand and Machine Labor. Washington DC: GPO. Available from HathiTrust.org: http://hdl.handle. net/2027/nnc1.cu08593957.

United States Senate (1893), Wholesale Prices, Wages, and Transportation, Report by Mr. Aldrich from the Committee on Finance, March 3, Part II.

Warren, George F. and Frank A. Pearson (1933), Prices, New York, John Wiley and Sons.

Wells, Tom (1998), "Nail Chronology: The Use of Technologically Derived Features," Historical Archaeology, 32(2), p. 78-99.

Wilder, Laura Ingalls (1935), Little House on the Prairie, Harper Collins, New York. 
Table 1

Sources of Real Price Change for Nails, 1790-2018

(annual averages over periods shown)

\begin{tabular}{|c|c|c|c|c|c|c|c|}
\hline & $\begin{array}{l}\text { Percent } \\
\text { change }\end{array}$ & \multicolumn{6}{|c|}{ Contribution of (in percentage points) } \\
\hline Period & $\begin{array}{c}\text { (1) } \\
\text { Nails } \\
\end{array}$ & $\begin{array}{c}\text { (2) } \\
\text { Capital } \\
\end{array}$ & $\begin{array}{c}\text { (3) } \\
\text { Labor } \\
\end{array}$ & $\begin{array}{c}\text { (4) } \\
\text { Energy }\end{array}$ & $\begin{array}{c}\text { (5) } \\
\text { Materials } \\
\end{array}$ & $\begin{array}{c}\text { (6) } \\
\text { Purchased } \\
\text { Services } \\
\end{array}$ & $\begin{array}{c}\text { (7) } \\
\text { Multifactor } \\
\text { Productivity }\end{array}$ \\
\hline 1791-1820 & -.37 & .03 & .66 & .01 & -.04 & .49 & 1.51 \\
\hline 1821-1860 & -1.89 & .00 & .84 & .00 & -.75 & .62 & 2.60 \\
\hline 1861-1880 & .45 & .08 & .30 & -.02 & -.11 & .15 & -.06 \\
\hline 1881-1930 & -2.89 & -.12 & .62 & -.02 & -1.30 & .23 & 2.31 \\
\hline 1931-2018 & 1.60 & -.04 & .75 & -.01 & .31 & .10 & -.48 \\
\hline Memo: & & & & & & & \\
\hline 1791-2018 & -.36 & -.03 & .69 & -.01 & -.31 & .28 & -.97 \\
\hline
\end{tabular}

Source: Author's calculations based on data plotted in figures 4, 5, and 6 .

Notes:

For each period shown, the percent change in the price of nails in column 1 is, by definition, the sum of the contributions of the factors of production (columns 2 to 6 ) less the contribution of multifactor productivity (column 7).

All prices are real prices, relative to the consumer price index described in the text. 


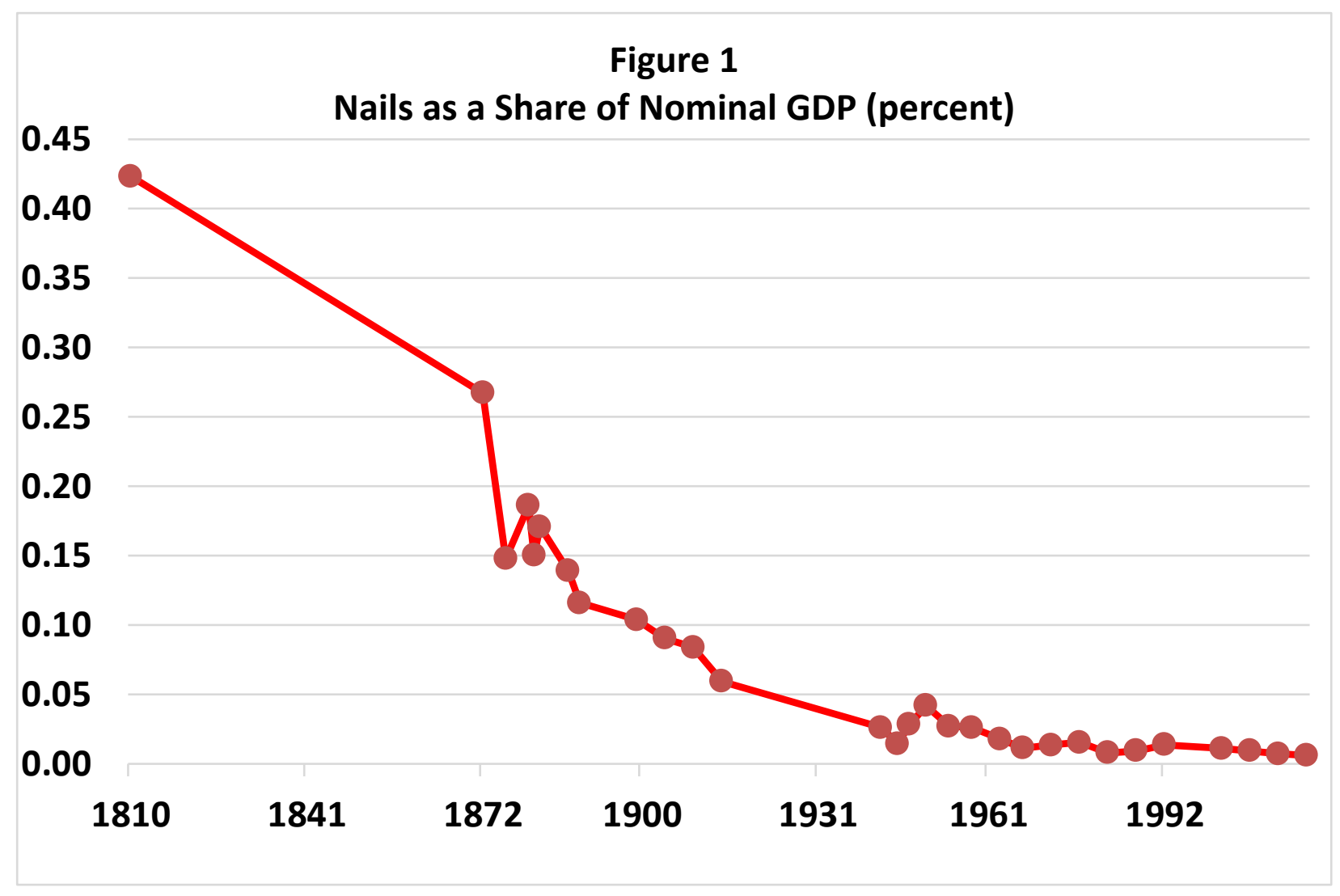

Note: The figure plots domestic absorption (production plus imports minus exports) as a share of nominal GDP. Data include nails, spikes, tacks, and staples. Data points are shown as dots connected by line segments. For underlying details of data and method, see the Appendix. 
Figure 2

Nominal Price of Nails, 1695-2018

(cents/lb)

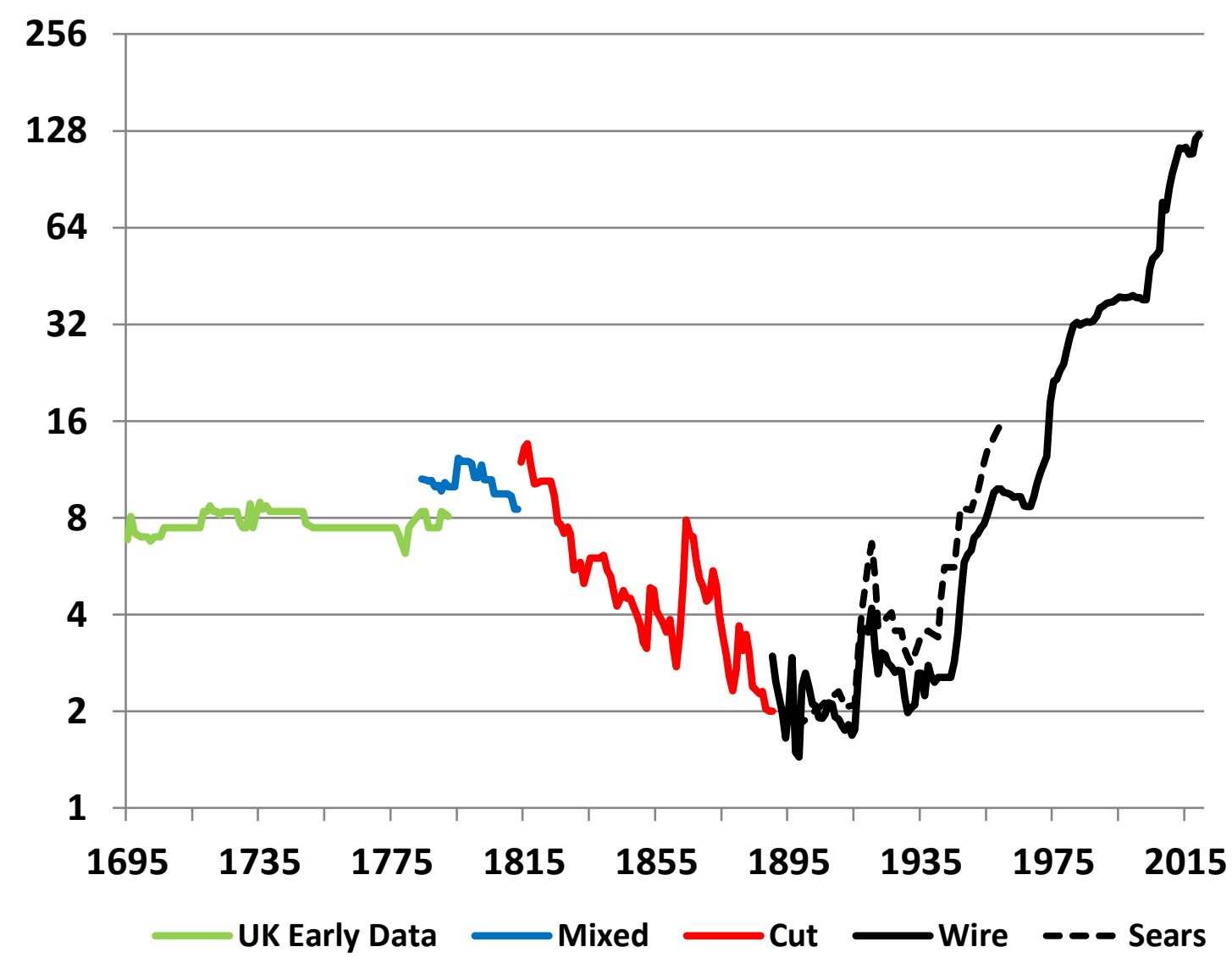

Source: Author's calculations based on Beveridge (1939), Cole (1938), Bureau of Labor Statistics Producer Price Index report, and other sources as described in the Appendix. 


\section{Figure 3}

Real Price of Nails, cents/lb (dashed) and cents/nail (solid) $2012 \$$ (relative to overall consumer prices)

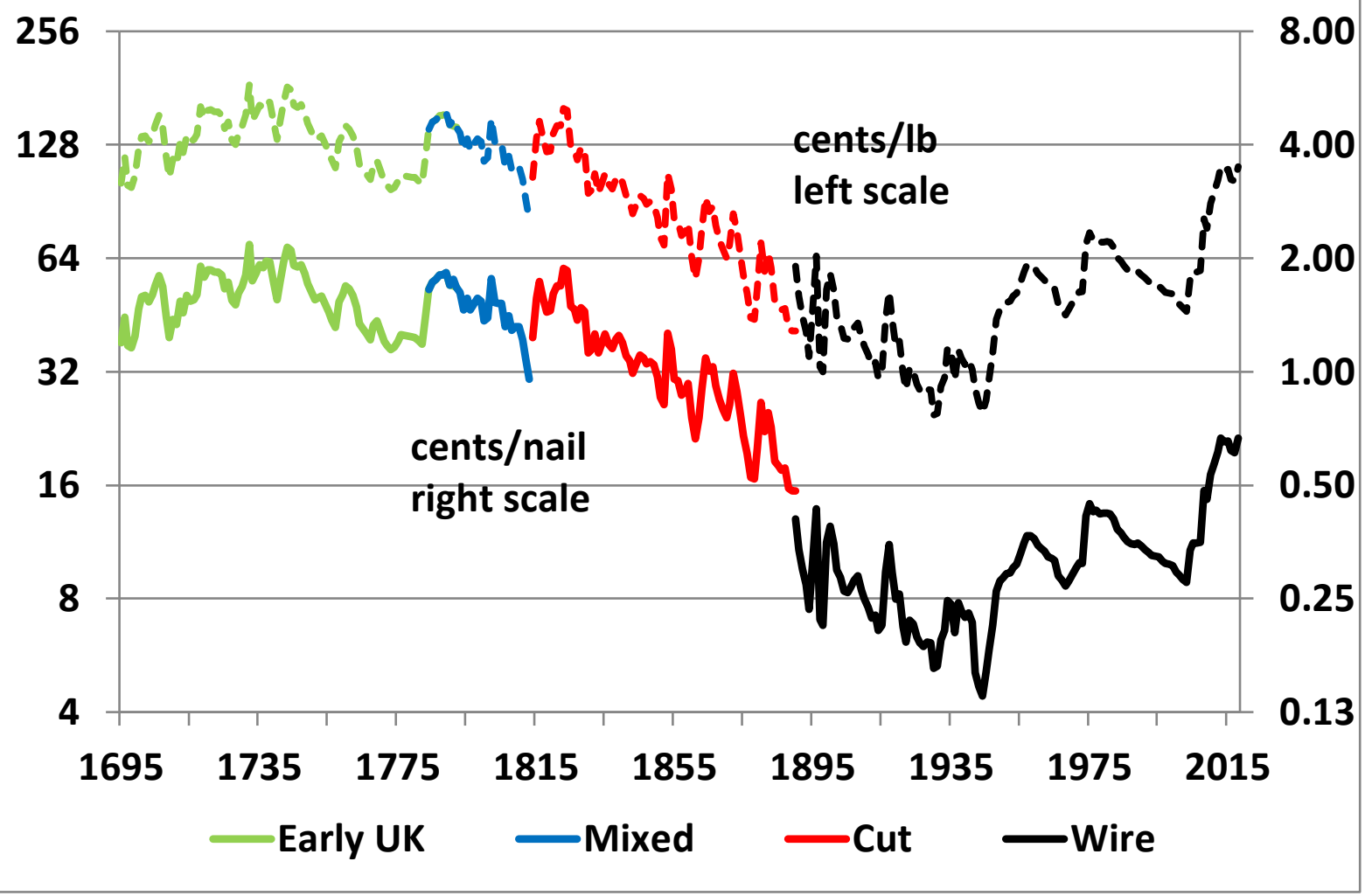

Source: Author's calculations using prices from figure 2, counts of the number of nails per pound as described in the text, and an index of consumer prices as described in the Appendix. 
Figure 4

Real Price of Nails: Matched-Model Index, 1695-2018 cents/nail $2012 \$$

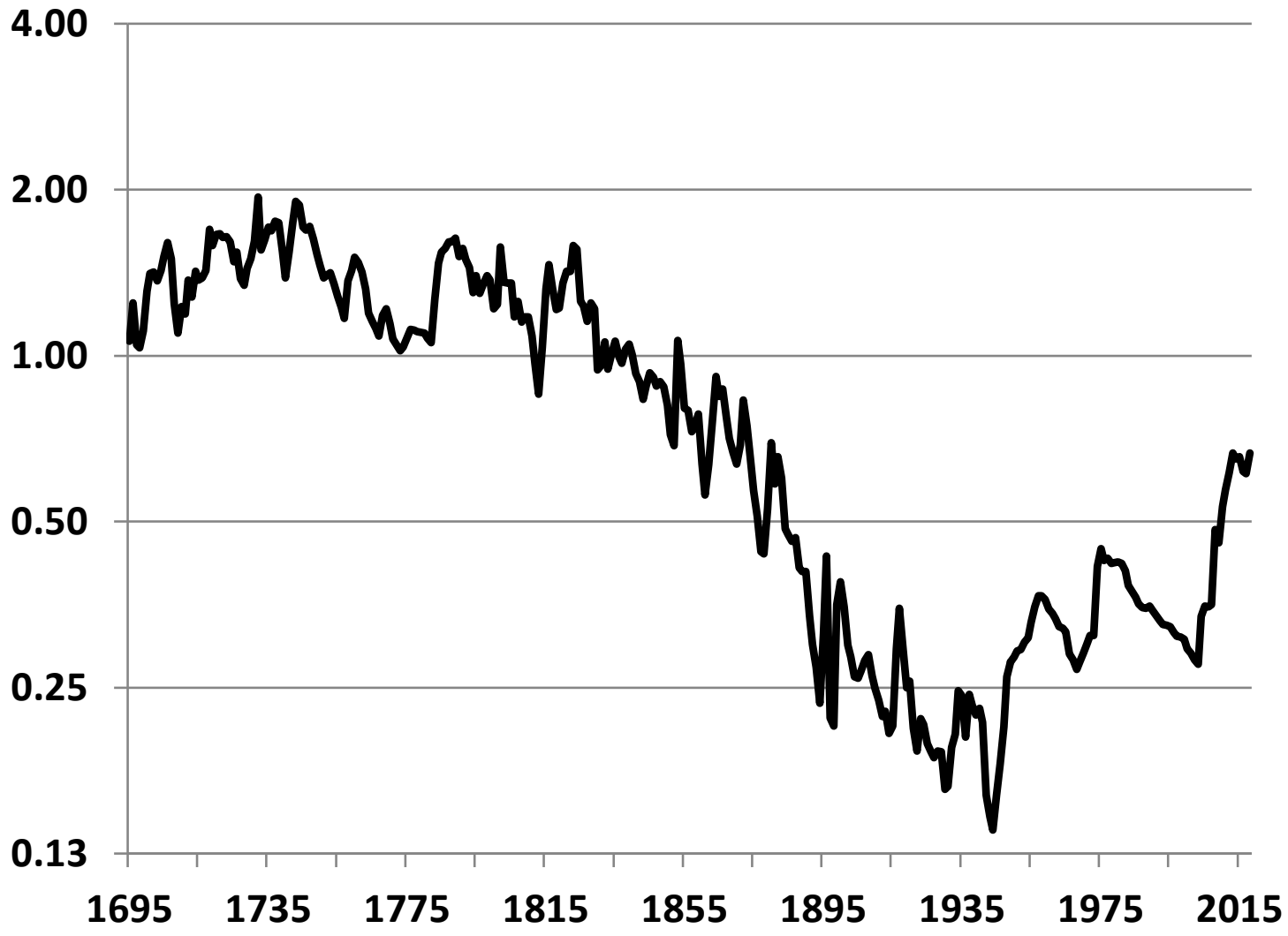

Source: Author's calculations based on prices shown by solid lines in figure 3 . 
Figure 5

Real Factor Prices, 1790-2018

$1790=100$

100000

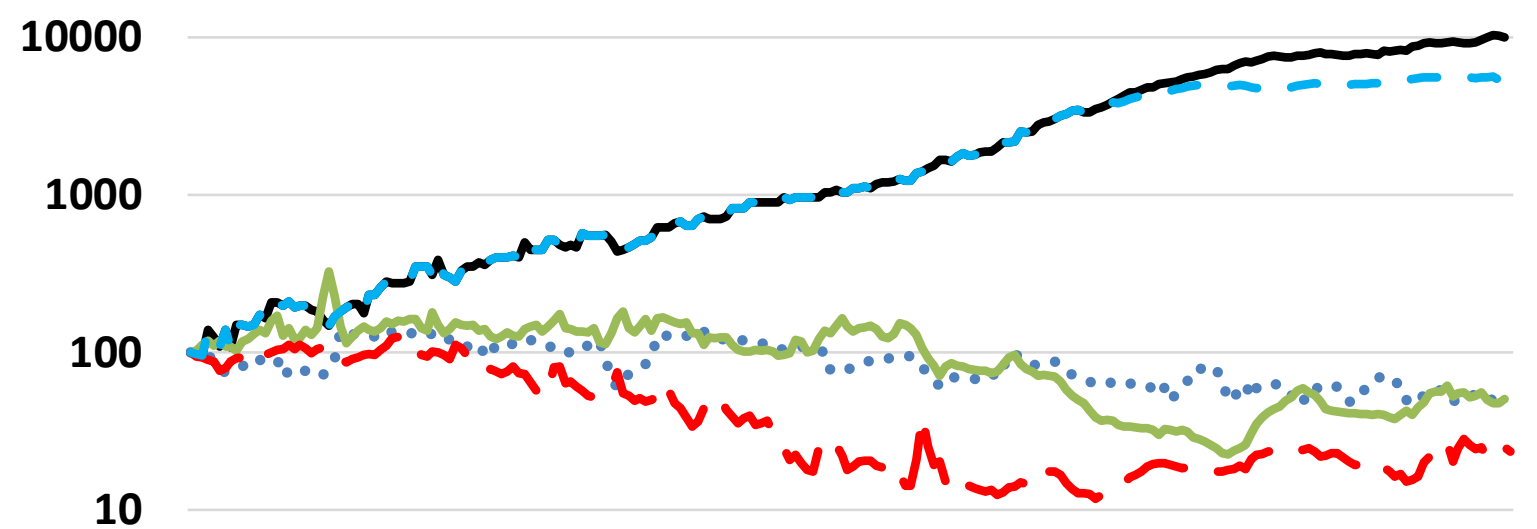

1

179018101830185018701890191019301950197019902010

..... Capital —Labor —Energy - Materials - - Services

Source: Author's calculations based on sources described in the Appendix. 
Figure 6

Factor Shares, 1790-2018

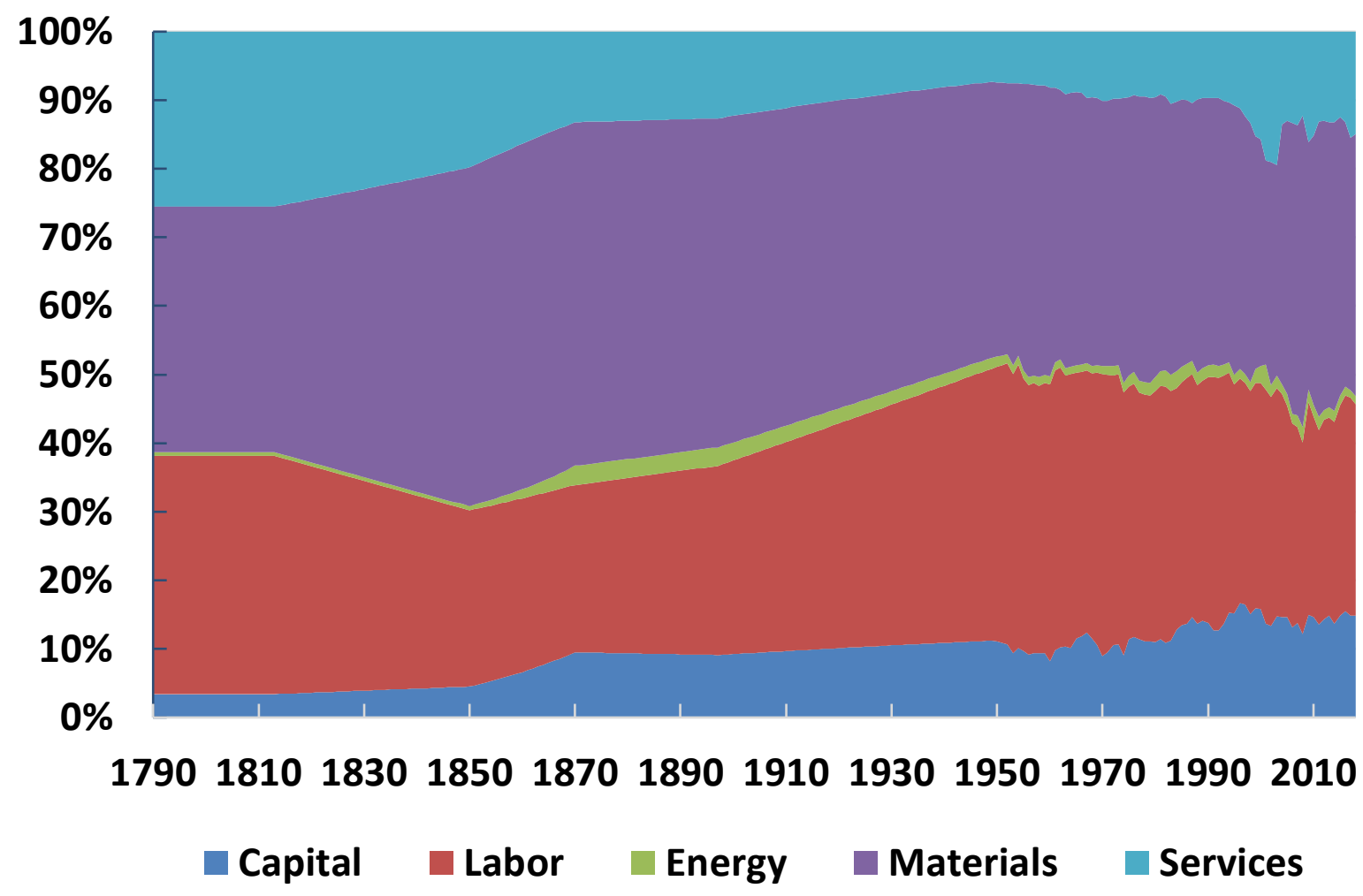

Source: Author's calculations based on sources described in the Appendix. 